\title{
Vistula River Valley in Cracow: from an Urban Barrier to a New Axis of Culture in the Scale of the City
}

\author{
Mateusz Gyurkovich ${ }^{1} \mid$ Karolina Dudzic-Gyurkovich ${ }^{2}$ | Agnieszka Matusik ${ }^{3}$ | Kinga Racoń-Leja 4
} Received: 2019-09-21 | in its final version: 2020-12-10

Abstract

\begin{abstract}
Cracow's city centre has witnessed the unsustainable development in recent decades. The shores of the Vistula River, which flows through it remains undeveloped, even along its downtown section. The river was and still remains in many points a major urban barrier, which divides the city. The research, which has been conducted for many years, consist of three elements. One is devoted to the hydrological, compositional and semantical role of the river in the city. Second focuses on defining the urban barriers. The third was devoted to the role of the buildings and complexes of culture, which were erected along Vistula for three decades. The objective of the research was to verify, using comparative analysis, whether it is possible to establish a new axis of activity, associated with those investments and its surroundings. Research results have demonstrated the high quality of most of the architectural forms of new buildings, and the accompanying public spaces. The riverside boulevards are also being subjected to transformation, but so far, in very small sections. The manner of linking these projects with the surrounding urban tissue still remains a problem, in addition to perceiving the river as an urban barrier. The small number of connections between both banks of the river is particularly surprising. In conclusion, it should be stated that the situation is slowly changing, including the bottom-up efforts. However, urban design and planning interventions are needed in the scale of the entire city, implemented with the broader view towards revitalisation of Cracow's riverside areas.
\end{abstract}

Keywords: blue-green infrastructure; cultural-urban transformation; urban heritage; unsustainable urban growth

Citation

Gyurkovich, M. et al. (2021). Vistula River Valley in Cracow: from an Urban Barrier to a New Axis of Culture in the Scale of the City. ACE: Architecture, City and Environment, 15(45), 9913 DOI: http://dx.doi.org/10.5821/ace.15.45.9913

\section{El valle del río Vístula en Cracovia: de barrera urbana a nuevo eje de cultura en la escala de la ciudad}

Resumen El centro de la ciudad de Cracovia ha sido testigo del desarrollo insostenible de las últimas décadas. Las orillas del río Vístula, que lo atraviesan, permanecen sin urbanizar, incluso a lo largo de su sección del centro. El río fue y sigue siendo en muchos puntos una importante barrera urbana que divide la ciudad. La investigación, que se ha realizado durante muchos años, consta de tres elementos. Uno está dedicado al papel hidrológico, compositivo y semántico del río en la ciudad. El segundo se centra en definir las barreras urbanas. El tercero se dedicó al papel de los edificios y complejos culturales, que se erigieron a lo largo del Vístula durante tres décadas. El objetivo de la investigación fue verificar, mediante análisis comparativo, si es posible establecer un nuevo eje de actividad, asociado a esas inversiones y su entorno. Los resultados de la investigación han demostrado la alta calidad de la mayoría de las formas arquitectónicas de los nuevos edificios y los espacios públicos que los acompañan. Los bulevares ribereños también están siendo sometidos a transformación, pero hasta ahora, en tramos muy reducidos. La forma de vincular estos proyectos con el tejido urbano circundante sigue siendo un problema, además de percibir el río como una barrera urbana. Sorprende especialmente el reducido número de conexiones entre ambas orillas del río. En conclusión, cabe señalar que la situación está cambiando lentamente, incluidos los esfuerzos de abajo hacia arriba. Sin embargo, se necesitan intervenciones de diseño y planificación urbana en la escala de toda la ciudad, implementadas con una visión más amplia hacia la revitalización de las áreas ribereñas de Cracovia.

Palabras clave: infraestructura azul-verde; transformación cultural-urbana; patrimonio urbano; crecimiento urbano insostenible

${ }^{1}$ Prof. DSc. PhD. Eng. Arch., Faculty of Architecture of Cracow University of Technology (ORCID: 0000-0002-66855234, Researcher ID: 2230027); ${ }^{2}$ Ph.D. Eng. Arch., Faculty of Architecture of Cracow University of Technology (ORCID: 0000-0002-9610-7288, ResearcherID: 3956081); ${ }^{3}$ PhD. Eng. Arch., Faculty of Architecture of Cracow University of Technology (ORCID: 0000-0002-8348-1254, ResearcherID: 2230732); ${ }^{4}$ Assoc. Prof., D.Sc. PhD. Eng. Arch., Faculty of Architecture of Cracow University of Technology (ORCID: 0000-0003-4762-8404, WoS ResearcherID: 2230449). Contact e-mail: mateusz.gyurkovich@pk.edu.pl 


\section{Introduction to the topic of urban barriers-selected issues}

Areas that constrain growth and the formation of linkages within their surrounding structure, forming as a result of a city's planned or spontaneous development, become barriers. When focusing on the forms that barriers can manifest themselves in urban structure, we can classify them as two primary geometric types: lines or surfaces, each affecting the tissue of the city in different ways. In a contemporary city, creating physical obstacles-barriers-can be used to, for instance, demarcate private property or to create a safe space. Compositional edges or "border strips" can also manifest themselves as barriers, which, depending on the spatial configuration, will constitute smaller or greater obstacles to the functioning of directions that are perpendicular to them. Barriers that penetrate or interfere with public space are perceived as a major threat, leading to the disintegration of the physical and social structure of contemporary cities (Dudzic-Gyurkovich, 2019).

Barriers can be formed by natural elements of the environment or topographic conditions, as history has demonstrated multiple times. At present, the presence of significant landscape elements and their relationships with built tissue most often leads to an appreciation of the city's assets and can become a defining factor in its attractiveness in a broader context. Distinct landscape elements were distinguished already by $\mathrm{K}$. Wejchert, who underscored their significance to the urban composition of the contemporary city (Wejchert, 2008). Water bodies (as surface elements) or rivers (as linear elements) have always been such elements, predominantly facilitating city development, being both sources of the water that cities needed to function and providing suitable transport routes (Nyka, 2013). They also played an important role in defensive systems, as impassable barriers - borders that impeded the advance of enemy armies. In a different manner than natural forms, barriers created because of a specific form of land development can possess negative characteristics. They become exterritorial areas within cities, typically hindering or blocking the free flow of pedestrian and local vehicular traffic, becoming a tear in or a border for the surrounding structure. Apart from the physical shape and size of a barrier, its function can also contribute to a place's exclusion, becoming another cause of the decay of its immediate surroundings.

Their initial classification (Dudzic-Gyurkovich, 2019) does not exhaust all the forms in which barriers can manifest themselves in contemporary urban layouts, as more complex configurations are possible, as are hybrid structures or the synergic impact of a range of functions that form a barrier together. An urban barrier is typically and intuitively understood as a border placed within an urbanised environment, although they currently do not have a definitive definition. In the Polish Language Dictionary, one of the descriptions of the term "barrier" is presented as follows: it is "(..) a natural obstacle, which hinders or prevents movement" (Stownik Jezzyka Polskiego, online, accessed on February 2017). In academic literature, the notion of the barrier appears in the context of the city and its form, referring to phenomena occurring at various scales. The problem of eliminating barriers, or rather designing space and its furnishings so that they can be used by all members of society, has been discussed in academic publications and constitutes a field of practical research (Benach, 2004; Parcerisa Bundó, 2014; Dudzic-Gyurkovich,2016). Such an explanation of the notion of the urban barrier terminologically refers to the urban environment, but it defines measures on a much smaller scalethe architectural, instead of the urban one. When searching for more comprehensive definitionswhich refer to phenomena on the scale of the city-we can find several approaches to interpreting this term. In a complicated and multi-layered structure such as a city, barriers can manifest themselves in various forms and at various planes. We should adopt the most obvious distinction as a basis for further discussion: between a barrier as a physical obstacle and a barrier that is the product of factors of a different nature (a psychological barrier, resulting from economic or political conditions). The role that a form or determinant that has been defined as a barrier plays in a city also appears significant. A general division based on the abovementioned indications can take on the following form (Dudzic-Gyurkovich, 2019):

ACE, 15 (4.5) CC BY-ND 3.0 ES | UPC Barcelona, Spain | Vistula River Valley in Cracow: from an Urban Barrier to a 2 New Axis of Culture in the Scale of the City. DOI: http://dx.doi.org/10.5821/ace.15.45.9913 
- A barrier as an element of the form of a city.

- A barrier as a constraint for urban development.

- Barriers and property ownership.

- A barrier as a tool used to create a safe space.

Three of these roles, seen as the most significant from the point of view of the article's main subject, which is changing the perception and functioning of rivers in cities (on the example of Cracow), will be briefly discussed below.

\subsection{Barriers as elements of the form of a city}

In an urban sense, a barrier can be formed by the perception-related or compositional edge of a certain area, as discussed by K. Lynch during the creation of his still-relevant instrumentarium for the analysis of urban space. In this perspective, the edge is a neutral term that can describe both positively and negatively perceived elements. An edge appears where areas with visibly different properties connect or touch, such as for instance, green and developed areas. It can also be a linear element of the terrain or land development, playing the role of a formal or compositional border. According to Lynch's typology, the following elements are considered to be edges: railways, shores, walls, as well as natural edges of developed areas (Lynch, 1960). In Poland, Kazimierz Wejchert introduced an analogous concept of border lines and strips, which he defined as "clear constraints or gaps between each region, district or development complex" (Wejchert, 2008). Understood as such, barriers are an indispensable element of existing tissue and they can, when used in an informed manner, constitute a tool in the planning of new areas of the city.

An interesting approach to the problem of barriers in urban development processes can be found in works from the field of geography, particularly the ones that focus on urban morphology. Scholars of urban structure, following M. R. G. Conzen, use the term "fixation line" to define linear structures that, during a certain stage, had constituted a constraint to a city's urban development (Conzen, 1960; Conzen, 2004). This term covers physical borders in the form of terrain topography, the outline of a city's walls or railway tracks, but it can also be used at the level of property, law or custom. As, among others, J. W. R. Whitehand has indicated, crossing an existing fixation line and territorial expansion beyond it leaves behind traces in a city's structure. Areas located inside such borders were subjected to concentration and densification processes, while the annexed fragments are typically characterised by lower urban density and a more freeform layout (Whitehand, 2006). Barrier-crossing and development leap processes are also linked with the notion of the "fringe belt", which defines the abovementioned set of characteristics displayed by development located in newly acquired, peripheral areas. Numerous publications concerning the form of the city and its development models have been devoted to this phenomenon. Fragments of relatively extensive structures emerged on the outer edges of well-defined layouts in periods of lower urbanisation dynamics. These dependencies were identified and formulated based on analysing historical processes; however, they are still relevant, such as in the case of processes that currently affect the form of the city (Kropf, 2017; Whitehand, 2007).

\subsection{Barriers as constraints to urban development}

Another group of factors that can be described as a barrier are economic and social forces that not only manifest within the space of the city but affect its form and the directions of its development. In his writings about processes that take place in the contemporary city, D. Harvey, an anthropologist and social theorist, stated-referring to R. Park's words-that if a city was a world that had been created by humans, it was also a world in which humans had to live from then on and that humans,

ACE, 15 (4.5) CC BY-ND 3.0 ES | UPC Barcelona, Spain | Vistula River Valley in Cracow: from an Urban Barrier to a 3 New Axis of Culture in the Scale of the City. DOI: http://dx.doi.org/10.5821/ace.15.45.9913 
directly and without being fully aware of the essence of their task, by creating the city, had transformed themselves as well (Harvey, 2012). Harvey also added that the right to the city was a right to change and to reinvent it anew in a form we want it to have.

The development of cities as territorial units, when looked at from an economic perspective, is determined by a series of properties that can positively or negatively affect development processes, increasing or decreasing their pace. Various barrier classification systems refer to their range, the interdependencies between the phenomena that create them or feasible means of overcoming them. From this perspective, a city's production, and service profile, if based on declining industry sectors or a lack of innovative activity or foreign and domestic capital, can also be considered a barrier. It should be assumed that, at present, it is the economy - the laws of the market-that largely controls urbanisation processes and does so to a degree that has never been seen before. The possibilities of a city's development-its territorial expansion or increasing its international or global significancedepends on the dynamic of the economy associated with, for instance, the presence of financial institutions or specialised multi-national corporations (Sassen, 1991), but also prestigious cultural institutions (Gyurkovich, 2013; Gyurkovich, 2019). Cities whose significance extends beyond national borders, and "global cities" to the greatest degree, are also characterised by above-average structure size and population density. Therefore, economic growth constitutes a stimulus to the formation of new structures, which is a process that has shaped cities since the beginning of human settlement.

We can also observe processes that go in the opposite direction when a market crash results in development processes coming to a halt and existing substance starts to decay. Financial crises with repercussions felt outside of countries that act as their epicentres, as argued by Harvey, are linked with property market crashes (Harvey, 2012). The phenomenon of shrinking cities-cities that consistently lose their population and shrink, is prevalent in Europe and is also observable in other countries. Contrary to global tendencies involving the urbanisation of increasingly greater territories, shrinking cities, as scholars have noted, are not a marginal phenomenon. It is caused by a set of several factors, among which the deciding role is ascribed to a worsening of the economy (Audirac et al., 2010; Haase et al., 2014; Oswalt, 2006). In the context of the potential for spatial development, understood as the growth of built substance, unfavourable economic and social conditions can constitute a cause of stagnation or regression, which is why treating them as one of the determinants of the form of the contemporary city is justified.

Successful examples of overcoming urban barriers show various possibilities, depending of typology of existing barrier, as well as of neighbouring urban structure. The large postindustrial or post-military zones, which were often excluded from the common use of citizens, are more frequently the subject of transformation and urban renewal. Such a processes have started in late 1980-ies in Western Europe, and a decade later in post-communist countries and were caused by the economic shift and global transfer of production markets. The growth of the towns and cities towards inside, into unused brownfields seems to be very sustainable (Mironowicz,2007). It may prevent the exaggeration of urban sprawl, which is especially dangerous in european conditions (Gyurkovich, 2013; Zuziak 2018). Starting from the most prestigious european examples: London Docklands, HafenCity in Hamburg, Eastern Docks in Amsterdam, Copenhagen and 22@Barcelona (Gyurkovich, 2013; Burda et al. 2017), finishing with more local interventions like Young City in Gdańsk (Matusik et al, 2020) and Zabłocie in Cracow (Gyurkovich et al, 2016; Konior et al 2020). On the other hand, linear barriers, such as highways, other busy roads, train trucks or rivers seems to be easier to overcome. But the investments connected with covering them with different kind of public spaces, buildings or just introduction of new crossing may be also very challenging. They have been widely introduced in different spatial situations all over the world. And they were mostly widely accepted by the users, primarily inhabitants of surrounding districts. Some of them have even gained international attention of professional critics (DudzicGyurkovich, 2016; 2018).

ACE, 15 (4.5) CC BY-ND 3.0 ES | UPC Barcelona, Spain | Vistula River Valley in Cracow: from an Urban Barrier to a 


\subsection{Barriers as elements of safe space}

The most fundamental role played by barriers is to impede or prevent movement in each direction. It is a tool used to stop undesirable persons or phenomena and exclude them from an enclosed space. In times of danger, historical cities were surrounded by fortifications, whose increasingly complex architecture was a response to changes in military tactics and engineering. In many cases, rivers that crossed a given city were included in the construction of defensive systems.

The character of the dangers faced by city residents has changed over the centuries. Urban space is not currently seen as a guarantee of safety. It is increasingly often the target of brutal terrorist attacks aimed at the civilian population, calculated to inflict the greatest possible number of casualties, which is why historical fortifications and water layouts can no longer be perceived as barriers against aggressors. Due to their high historic value, their conservation and adaptive reuse should be a priority in the current era of sustainable city development (Kadłuczka, 2015; Gyurkovich, 2019; WęcławowiczBilska, 2019). Their role in the space of this is changing, they are becoming tourist attractions that build the sequences of the most important public spaces of the city, something that has taken place in many European centres (Girona, Dubrovnik, Carcassonne) and is also slowly being implemented in Polish cities (Gdańsk, Cracow, Warsaw, Modlin).

\section{The city’s hydrological system as a barrier}

The location of the oldest settlements, which were transformed into towns and cities has been very often connected with the access to fresh water. Despite this predominant function, rivers in cities were used for different purposes: as trade routes, as the elements of defensive systems (which was already mentioned), as the source of energy for mills, manufactures, and for industry at the all stages of development, finally also as a transport system (like in Amsterdam of St. Petersburg) and -latelyas recreational public spaces of the cities. The problem of rivers and streams in the cities is still very actual and present in scientific books and papers (Nyka, 2013; Durán Vian et al., 2020). Many of rivers in towns and cities were regulated or put in underground canals in the sake of the 'development' of urban structures. Many were contaminated by sewage and industry, especially in $19^{\text {th }}$ and $20^{\text {th }}$ centuries. Never the less, rivers (usually together with the surrounding greenery) within the towns and cities remains very often the major ecological corridors of regional, and sometimes even international importance.

The perception of a city's hydrological system as a barrier has its historical justifications, however, it should be completely disregarded in the contemporary understanding of the city's spatial structure. Unfortunately, in the case of many Polish cities, due to the destruction of river crossings during wartime operations of the First and later the Second World War, as well as insufficient funding during the period of the People's Republic of Poland (1945-89), rivers and their immediate surroundings ceased being "life-giving urban arterials" and have become nigh-impassable barriers that crisscross urban tissue-on par with railway grounds and busy arterials. A psychological barrier in the form of a river that divides the more privileged areas of the city from those deemed less so, is also currently present in many European urban centres, such as London, Szczecin, Gdańsk (Matusik et al., 2020) and Warsaw (Matusik, 2018a). Its neutralisation is typically performed by initiating numerous regeneration processes in waterfront areas, both in the spatial and socio-economic sense. Vistula is the longest of Polish rivers, which flows by entire country - from the mountains in the south, to the Baltic Sea in the north (Matusik et al, 2020). That is why it still is perceived as one of the main ecological corridors in this part of Europe, which helps to preserve biodiversity. In many cities it still remains partly wild, like in Cracow (Figure 1), Torun or Warsaw. The collision of partly natural landscapes of the river valley with the townscapes of the cities gives it exceptional values. Such a situations of coexistence of wild areas and the urbanized ones are, generally speaking very interesting, and have found the reflection in contemporary research (Benedet et al, 2020; Chávez Alaffita et al., 2020).

ACE, 15 (4.5) CC BY-ND 3.0 ES | UPC Barcelona, Spain | Vistula River Valley in Cracow: from an Urban Barrier to a 


\section{ACE Architecture, City and Environment}

E-ISSN 1886-4805

Figure 1. Vistula in Cracow - transformed and wild river boulevards on the opposite banks

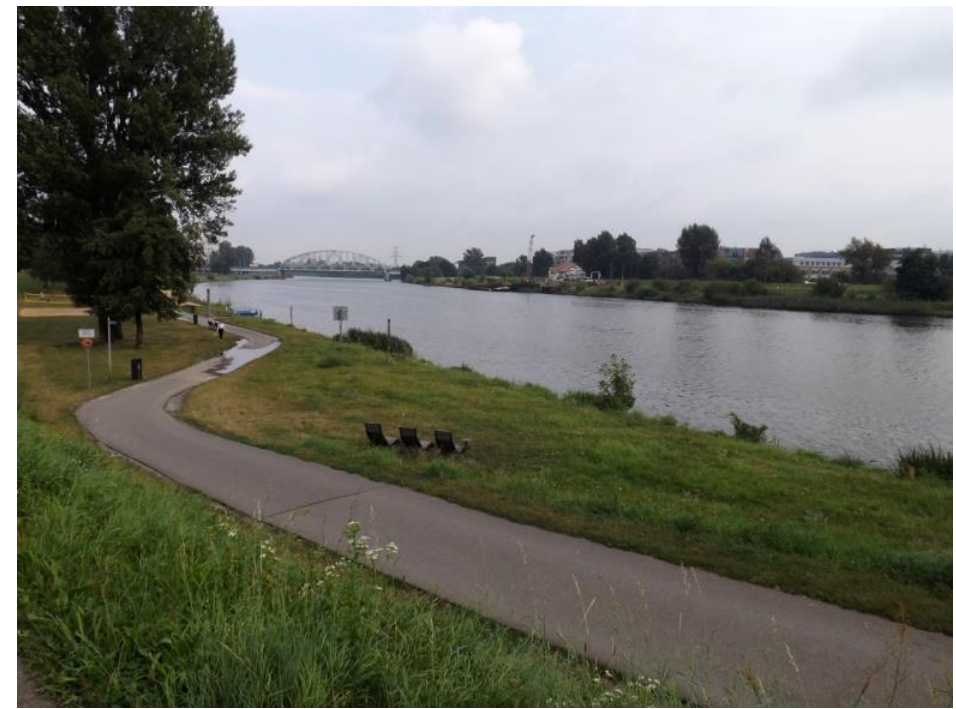

Source: photo by M. Gyurkovich, 2020

The history of Cracow's urban development has led to a situation in which the Vistula river and its numerous inflows of smaller scale (e. g., Rudawa, Wilga to name those which intervene with the innercity part of the river valley) were-and sometimes still are-perceived as urban barriers. They seem to hinder the functioning and development of the city (Gyurkovich et al., 2017), instead of being one of the potential attractors of public space like it is happening again very often in other metropolitan cities in Europe (Matusik, 2018b; Seruga, 2018). Rivers in Cracow are still malfunctioning elements of urban structure (Figure 2), even though, the city authorities have approved the plan of creating active river-parks along them in late 1990 (Gyurkovich et al., 2016; Nowacka-Rejzner, 2019).

Figure 2. Vistula River on the background of spatial structure of the city of Cracow -current state

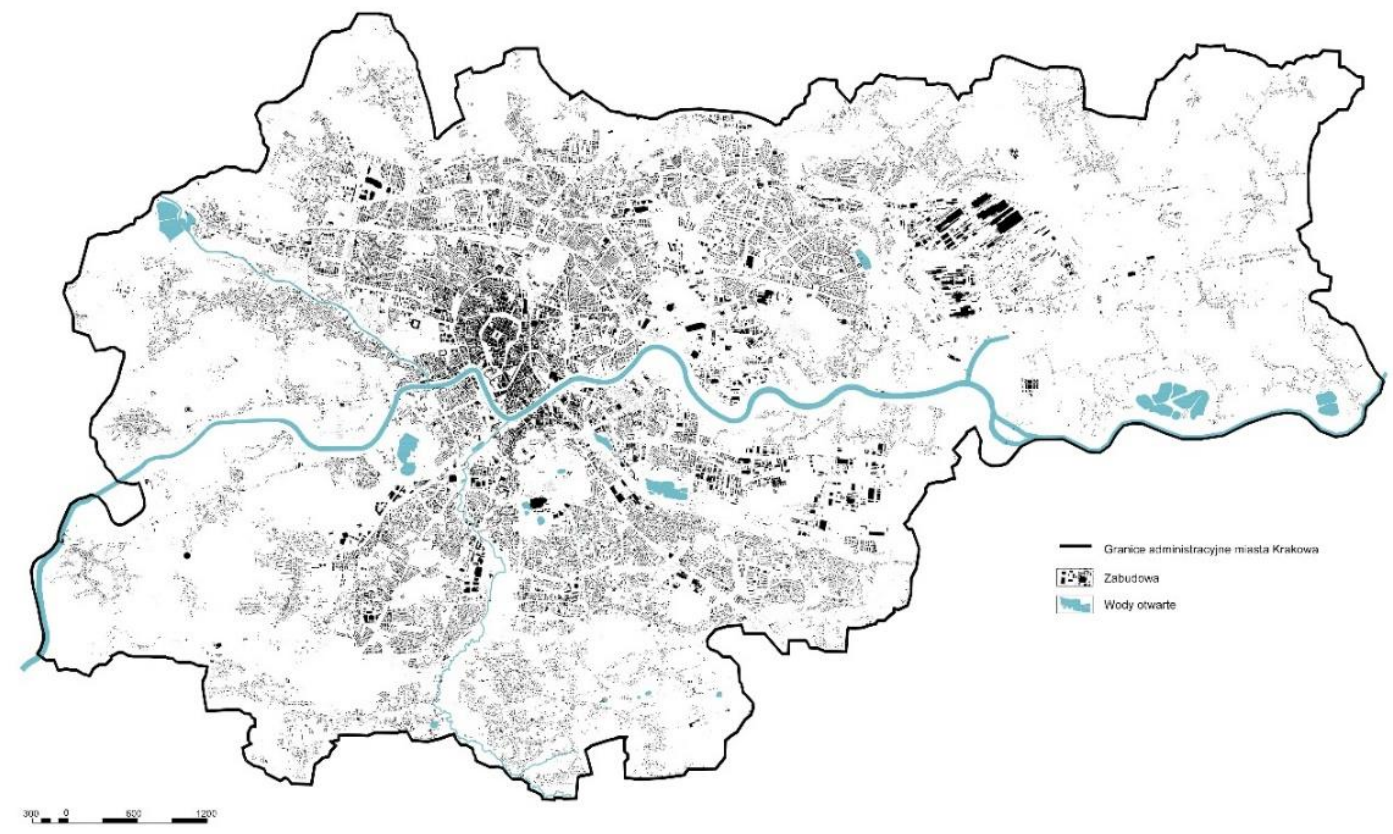

Source: Drawn by P. Tota (Gyurkovich et al., 2017), courtesy of Cracow City Council

ACE, 15 (4.5) CC BY-ND 3.0 ES | UPC Barcelona, Spain | Vistula River Valley in Cracow: from an Urban Barrier to a New Axis of Culture in the Scale of the City. DOI: http://dx.doi.org/10.5821/ace.15.45.9913 


\section{ACE Architecture, City and Environment}

As for now, in entire city (of ca. 1000000 inhabitants) there is only one pedestrian crossing over the Vistula River - Bernatka Bridge (Figure 3). Other bridges combine the roads for cars, sometimes with tram trucks, which are accompanied by usually narrow sidewalks (Fig.4). Altogether (except of train bridges) there are just 10 bridges (including 2 highway passes) over the Vistula within city limits on the length of about $15 \mathrm{~km}$, which makes it hard to cross by any mean of transportation. Therefore, the river is still remaining the functional barrier for large parts of the city.

Figure 3. Bernatka Pedestrian Bridge between historical districts of Kazimierz and Podgórze in Cracow

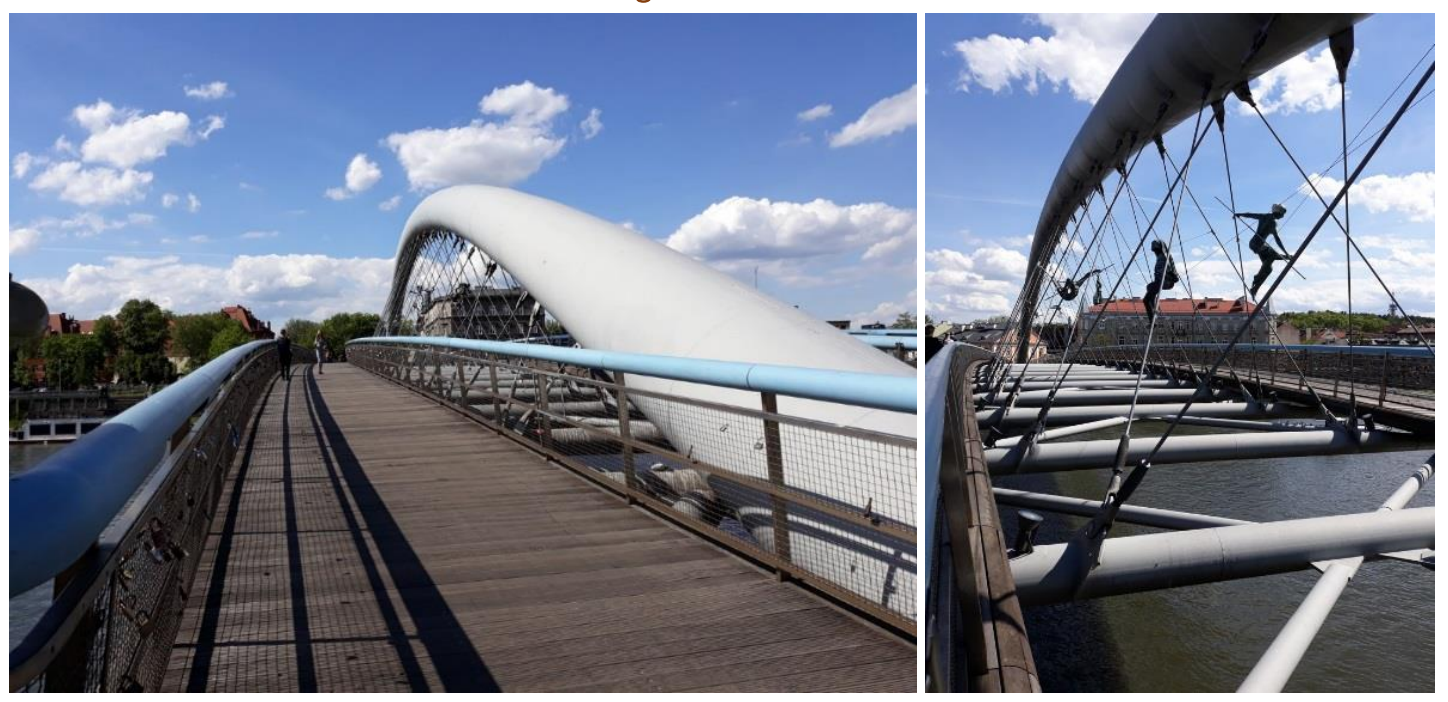

Source: photo by M.Gyurkovich, 2019

Figure 4. Kotlarski Bridge in the city centre of Cracow is perceived as one of the more pedestrian-friendly bridges in the city
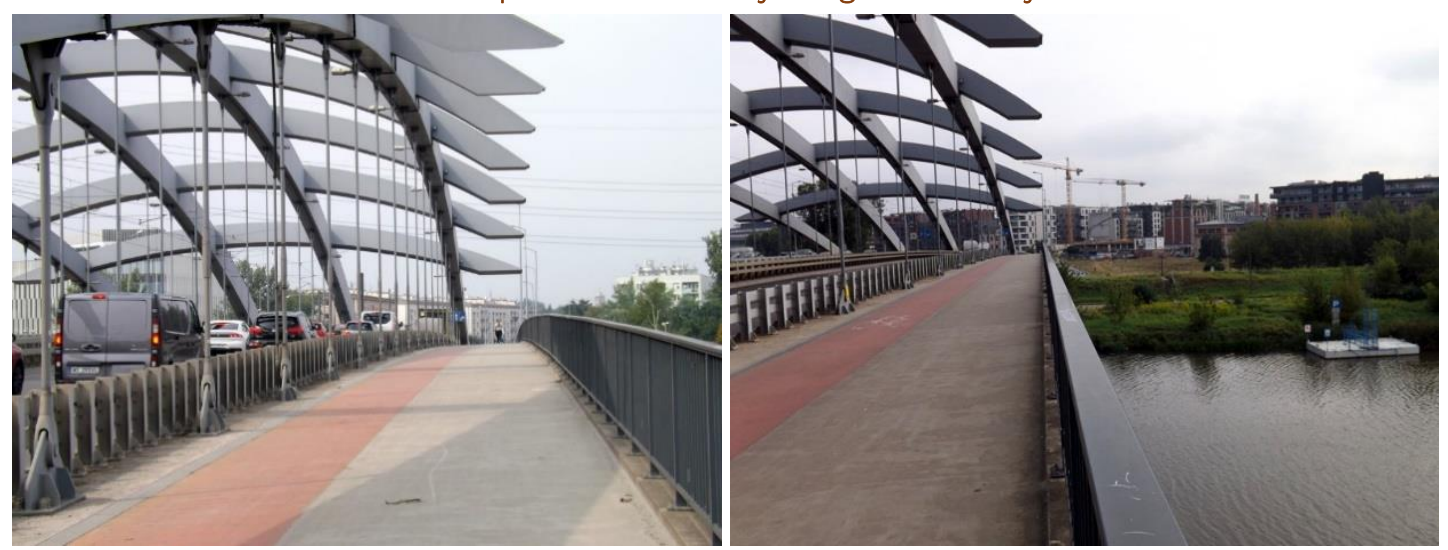

Source: photo by M.Gyurkovich, 2020

The planned river parks were never completed, except of small fragments here and there, unfortunately also not in the most demanding and representative places, like the portion of the Vistula River valley in the inner-city, visited by millions of tourists yearly. Those small, improved pieces of river-parks are not creating the continuity of blue and green public spaces, as corridors of activities which could link different districts in the scale of entire municipality of Cracow (Gyurkovich et al., 2017; Ziobro, 2018).

ACE, 15 (4.5) CC BY-ND 3.0 ES | UPC Barcelona, Spain | Vistula River Valley in Cracow: from an Urban Barrier to a 
The attempts of placing attractive investments - as well complexes, as individual buildings - including those devoted to culture, that have the potential power to change this situation, have been made in recent decades (Zuziak, 2018; Gyurkovich, 2019). Unfortunately, there is little to speak of in terms of the proper planning of projects that have been built over the course of many years. Despite the formal attractiveness of individual buildings and complexes, there is a visible lack of coordination between them and the entire system of public spaces, particularly pedestrian ones. The still small number of circulation linkages between both sides of the Vistula river is particularly surprising. This situation is largely a result of the planning crisis that we have been dealing with since 2003 in Poland's largest cities. Two among the authors of the paper (M. Gyurkovich and A. Matusik) were taking part in a research and development documentation commissioned by the Office of the City of Cracow in 20162017, which featured a method of addressing this unfavourable situation (Gyurkovich et al., 2017).

\section{Outline of Cracow's urban development - the role of the Vistula River valley}

The oldest districts of some historical cities in Europe are becoming depopulated, turning into prestigious tourist areas filled with public buildings featuring various functions, as well as with hotels. Similar transformations have also happened in Cracow's strict city centre in recent years. Cities and settlement complexes in Europe were often founded near rivers, which were the basic passenger and goods transport routes during the early stages of the continent's urbanisation (Mumford, 1961; Nyka, 2013). The matter was no different in Cracow, whose beginnings can be traced to Wawel Hill, located amid the wetlands near a river bend of the Vistula (the longest river in Poland), itself a princely gord that had been periodically associated with the Great Moravian Empire and, since the tenth century, with the then-newly-formed Principality and later Kingdom of Poland. Over time, the settlements that emerged around the then-royal residence atop Wawel Hill coalesced into one urban organism, but it was primarily the economically and militarily strategic location near the Vistula River that caused Cracow to replace Gniezno as the state capital. The presence of the river as the main economic artery-effectively up to the end of the nineteenth century-was one of the driving forces behind the city’s development (Izdebski and Szmytka, 2018).

Cracow's urban plan, delineated based on a town charter privilege from 1257, is seen as the most impressive built version of the Medieval model of an ideal city with a geometric, chessboard like gridbased plan, deformed by relics of previous settlement layouts (Encyklopedia Krakowa, 2000). “(...) in the twilight of the Middle Ages, Cracow was a complex of three towns - a tricity - located along the north-south axis, acting as the economic, religious, and cultural centre of Poland with well-organized urban structures and of high military importance. The polycentric urban layout Cracow-KazimierzKleparz was in its prime in the 15th, 16th, and 17th centuries (...)" (Gyurkovich, 2012, pp.257). From among the many towns, cities and villages that developed during subsequent centuries in contemporary Cracow, of note are two settlement centres that were founded and developed by foreign powersand which are legible to this day in the city's plan and are still present in the public conscious as important and crystallised elements of the city's polycentric structure. They were founded in the immediate vicinity of the city, to compete with it and discredit its economic, political, cultural, as well as symbolic role-as the former capital of Poland. As history has shown, these plans failed, leading to the emergence of new satellite urban layouts relative to the core metropolis instead, and have influenced the current image of the city.

The first of these towns was Podgórze, squeezed into the area between the southern shore of the Vistula and Krzemionki Hill, opposite of Kazimierz, which was a continuation of Cracow's urban development along its north-south axis. The town was founded by the occupying Austrian government, which-after the first partition of Poland in 1772-took the land to the south of the Vistula

ACE, 15 (4.5) CC BY-ND 3.0 ES | UPC Barcelona, Spain | Vistula River Valley in Cracow: from an Urban Barrier to a 8 New Axis of Culture in the Scale of the City. DOI: http://dx.doi.org/10.5821/ace.15.45.9913 
(which then became a barrier - a political border -for over two decades). In 1784 the Austrian emperor Joseph II Habsburg issued free royal town rights to the village that had existed at the site since the Middle Ages and that, over time, had transformed into a suburb of Kazimierz. Constrained by difficult geographic conditions, the town developed primarily along its main circulation sequences, associated with the former trade route from Silesia to Hungary that crossed through the newly created urban organism from east to west. Meant to economically compete with the Polish tricity (CracowKazimierz-Kleparz), the Austrian Podgórze received urban regulations in 1789, which resulted in its triangularly-shaped market square.

The administrative separateness of Podgórze was maintained up to August 1914, which caused the perception of the inner-city section of the Vistula as a barrier to take strong root in the public conscious. This was also exploited by the Nazis, who established a ghetto on the same bank of the river as Podgórze during the Second World War. This, in turn, affected the spatial development of the district in the second half of the twentieth century (Purchla, 1990; Encyklopedia Krakowa, 2000; Gyurkovich, 2012; Gyurkovich et al., 2016). The other important town (currently a district) was Nowa Huta, whose construction was commissioned by the USSR (construction started in 1949), and whose placement and later incorporation into Cracow in 1951, along with its connection with the historicallyshaped centre, has completely altered the previous direction of the city's spatial development (Encyklopedia Krakowa, 2000; Gyurkovich, 2012).

The urban structure of contemporary Cracow, like that of any city, is defined by the skeleton of its spatial layout, set by its easily identifiable urban units ( in urban composition theory regarded as : regions/ areas) (Lynch,1960; Wejchert,2008), or-using a different distinction-morphogenetic units. The delimitation of those units for the state in 2016 was performed based on the structural urban units featured in the applicable (still- April 2020) Spatial Development Conditions and Directions Study of the City of Cracow of 2014 (Gyurkovich et al., 2017; Dudzic-Gyurkovich 2018). They remains interconnected with the city's transport system, elements of which can be defined according to numerous theories concerning urban composition as: lines/edges, and about the methodological assumptions of the Model of the Spatial Structure of the City of Cracow (MPSK), as grids-as defined in the interdisciplinary stage II study (Gyurkovich et al., 2017). In theory, their mutual compositional relations should be legible both when viewed on the plan and-perhaps most importantly-in 3D, in the actual spatial structure of the city. Thanks to these measures, the extant urban composition, as an urban form, should make spatial orientation easier for its users, even those who do not know the city too well (Kantarek, 2008; Kantarek, 2014).

The history of the city's urban development, especially the period of Austro-Hungarian occupation (1795-1815 and 1846-1914), especially the second half of the 19 $9^{\text {th }}$ century, when the city was converted into a fortified stronghold, led to a situation in which low-density built-up areas can still be found in the immediate vicinity of the city centre, appearing as if they are peripheral areas. In morphological terms, Cracow, apart from its historic centre, confined to the so-called first and second ring-roads (Porębska et al, 2019), along with the oldest part of Nowa Huta, remains a city that is not compact. It is difficult to find a large-scale urban composition of the entire urban structure, that would be adequate to its metropolitan status, as the second largest city in Poland. The strict historical centre, due to its considerable number of institutions of culture, including several latest constructions, like the Underground Museum underneath the Main Market Square (Kadłuczka, 2010; Gyurkovich, 2013) that exhibits the hidden city's urban development, can be considered a hybrid cultural district (Jagodzińska, 2008; Gyurkovich, 2013).

In the latest studies concerning creative areas as creative syntax leading to the stimulation of innercity areas, the area inside the second ring-road was identified as key to Cracow's identity (Pazder, 2018). It is, therefore, necessary to expand its linkage network, which has already been postulated earlier (Gyurkovich et al., 2017). Apart from the compact city centre, the individual complexes, and sections of the city's districts, interconnected in a more or less effective manner through the transport

ACE, 15 (4.5) CC BY-ND 3.0 ES | UPC Barcelona, Spain | Vistula River Valley in Cracow: from an Urban Barrier to a 9 New Axis of Culture in the Scale of the City. DOI: http://dx.doi.org/10.5821/ace.15.45.9913 
system (along with a considerable deficit of effective rail-based transport), significantly differ from each other in terms of urban density, form and development structure. This is usually a situation encountered in cities with many centuries of tradition, which-similarly to Cracow-have developed in leaps, rather than in a harmonious manner, over the centuries. In Cracow, there are typically no legible spatial connectors between the various parts of the city. It is difficult to acknowledge mere circulation routes without friendly, accessible, safe, and walkable public spaces as proper connectors. The city's roads and railway lines are currently seen as urban barriers separating the districts on either of their sides, with the Vistula River being seen in a similar manner (Nowacka-Rejzner, 2019).

\section{The Vistula River valley in Cracow as a new axis of culture}

Despite all of this, the inner-city section of the Vistula River deserves particular attention (Fig. 5) as a natural compositional element (a barrier that has shaped the landscape of the city for centuries). Due to the post-war transformations of its waterfront areas, the city was, in essence, "facing away" from the river and its presence was not clearly felt. Its riverside boulevards did not offer friendly public spaces, and even today their quality leaves much to be desired. Because of this, in 1998, a discussion started about the $7^{\text {th }}$ International Architectural Biennale in Cracow: Facing the Water. The interesting designs that were submitted for the competition covered the areas occupied by the riverside boulevards: Czerwiński, Poleski, Podolski and the mouth of the Relief Canal that had been designed since Austrian times and never completed (Racoń-Leja, 2011) - namely, the section of the river in the very heart of the city. As a conceptual competition, the Biennale did not, however, bring with it any actual spatial results, nor did it significantly affect later planning documents (Gyurkovich et al., 2016).

Despite this, another urban and architectural design competition was organised in 2008 for the design of the same area. The co-authors of this article (K. Dudzic-Gyurkovich and M. Gyurkovich) were among the prize-winners, proposing a modern development of the boulevards that was accessible to all, with a hybrid cultural building at the site of a late-modernist hotel that had been suggested for demolition (Dudzic-Gyurkovich and Gyurkovich, 2008). Its abandoned massing rises still above the southern shore of the Vistula, on the river bend, directly opposite the Na Skałce monastic complex, which, along with Wawel Hill, have constituted the major cultural landmarks within this townscape. The lower storeys of the abandoned structure are used as a restaurant, exhibition, and popular event space, has constituted an interesting programmatic supplementation of the boulevards for some years now. It appears the matter is still relevant: the 2019 Cracow International Architectural Biennale also focused on the city's linkages with the river. Its curators have highlighted the necessity to change the perception of the inner-city section of the Vistula River: "As the role of the historic European city centres changes, from an industrial base to a recreational, cultural, and educational role, the situation of the urban rivers changes as well. The Vistula River running through Kraków, was once the central artery of transportation for the urban economy. That has changed. The river now gives the city a major recreational quality, with calm waters and green banks. Could this relationship between the city and its river now be reinterpreted, be given a stronger connection, a boost with new facilities, some new life and new functions, a new significance for the whole urban environment?" (Międzynarodowe Biennale Architektury, 2019).

In the perspective of the city's development up to the year 2030 or even 2050 that was adopted in the research study prepared in the Institute of Urban Design (Gyurkovich et al., 2017), it was assumed that the Inner-City Vistula River Valley Park will constitute a structural and functional connector within the city's structure and will be based on ecological assets. It is the city's main green corridor, according to the guidelines of both applicable and earlier planning documents, in which the concept of "river parks"-green areas of particularly high value in the spatial structure of Cracow-that was formulated by A. Bohm in 1994 (Gyurkovich et al., 2016), is still featured. It should be integrated with green perpendicular channels, linked both with the existing boulevards of the Vistula's tributaries, as well

ACE, 15 (4.5) CC BY-ND 3.0 ES | UPC Barcelona, Spain | Vistula River Valley in Cracow: from an Urban Barrier to a 10 New Axis of Culture in the Scale of the City. DOI: http://dx.doi.org/10.5821/ace.15.45.9913 
as new sequences of greenery, which connect the urban structure along the north-south direction. Because of this, the public spaces that already exist along the river would be incorporated into the city's system of generally accessible pedestrian and bicycle spaces. This requires the construction of additional bridges for both bicycles and pedestrians, a system of which has also been proposed in the same document (Gyurkovich et al., 2017).

Figure 5. Inner-City Vistula River Valley (existing state)- desirable connections and river as urban barrier with only one pedestrian crossing (Bernatka Bridge)

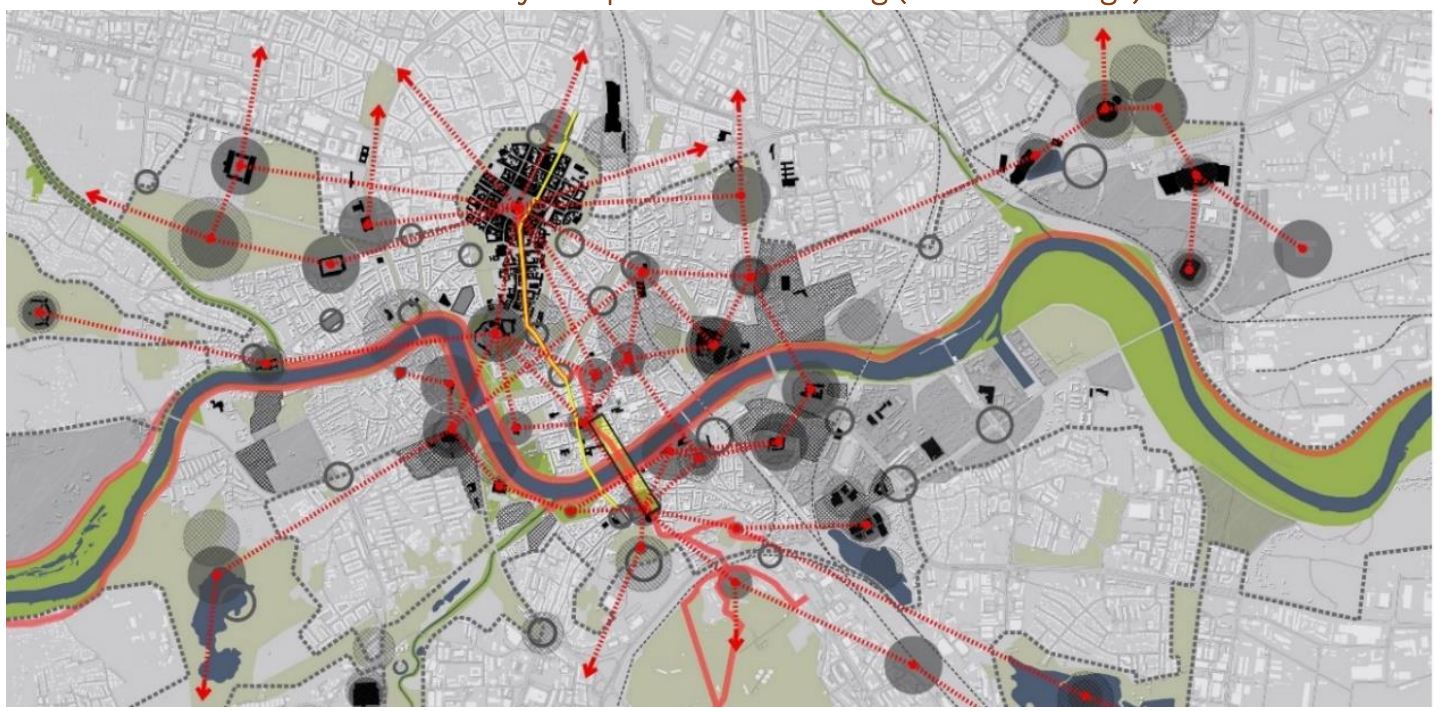

Source: Drawn by A. Sarga (Gyurkovich, et al., 2017), courtesy of Cracow City Council.

Apart from the most valuable urban structures that have come to form the current centre of Cracow, numerous industrial and storage buildings were built along the Vistula-primarily on the shores near Kazimierz and Podgórze-as it was a suitable waterway, in use since the Middle Ages. Many of them functioned almost up to the end of the twentieth century. At present, these areas are undergoing a transformation that does not appear to be fully under the control of planners. It is in this fragment of the city that successive complexes and buildings associated with cultural functions have been more or less consistently planned and built for several decades now.

\subsection{New cultural objects and hybrid cultural complexes within the Inner- city portion of the Vistula River Valley in Cracow}

The Manggha Museum, built in the most demanding fragment of the boulevards, opposite Wawel Castle, on the Dębniki section of the Vistula's shore, began operating towards the end of the previous century. Designed by Arata Isozaki in cooperation with the Cracow-based design company owned by Krzysztof Ingarden and Jacek Ewy, museum was built over a period of only 15 months and opened in November 1994 (Gyurkovich, 2019). A difficult and troublesome plot was selected as the site of the museum - a wedge of undeveloped land between a floodwall delimiting the boulevards and a busy circulation arterial forming a fragment of the city's second ring-road considered as a significant urban barrier, as well as the then-decayed development of the eastern fragment of the district of Dębniki. Manggha has become a catalyst for change in its immediate neighbourhood, as well as in a broader context-that of the stimulation of the public space of the boulevards along the southern shore of the Vistula. The building was the first large contemporary project featuring a cultural institution after the fall of communism in Poland. It is very modest and, despite its contemporary architecture featuring high-value aesthetic qualities, it perfectly blends into the extant spatial and cultural context. The roof is the building's most important part, observed by millions of people each year from Wawel

ACE, 15 (4.5) CC BY-ND 3.0 ES | UPC Barcelona, Spain | Vistula River Valley in Cracow: from an Urban Barrier to a 11 New Axis of Culture in the Scale of the City. DOI: http://dx.doi.org/10.5821/ace.15.45.9913 
Hill. Isozaki referred to the waves of a river in its form, while also using perfect top and side light to illuminate the interiors of the building. The path to the main entrance to the structure, or rather a small hybrid culture complex, which has "sprouted" around the building, runs from the side of public transport stops near the busy arterial (Gyurkovich, 2019). The architects managed to create a sequence of cameral, elegant public interiors along this noisy street, a sequence that is harmoniously composed with the restrained architecture of the buildings, fully diverting our attention from the spatial chaos surrounding this enclave. It is a true space of culture, complementary to its surrounding dynamic city structure that is unfriendly to man.

Going along the river and its shore, on the opposite side of the street and its busy roundabout, we can see the monumental building of the ICE Krakow Congress Centre. The building was built as the effect of a two-stage architectural and urban design competition organised by the City of Cracow in 2007. The massing, designed by the authors of the Manggha Museum (Słącz, Ingarden; 2014), has nothing in common with the simplicity and tranquility of the previously discussed modern complex. Its role in the space of the city is different. Placed on a corner plot, near a busy transit route, it is a symbol. It is meant to be one of the new hallmarks of the city. It delineates the line between the historical town and its diversely granulated tissue and the modern city. This border space is composed of modern office, commercial and hotel buildings, forming a barrier between the nearby Podwawelskie Housing Estate (Encyklopedia Krakowa, 2000) and the circulation route that runs along the riverside boulevards, forming a double barrier in this part of the city (Dudzic-Gyurkovich, 2018).

The ICE Krakow Congress Centre is an element of the sequence of the riverside frontage of the city along the section that is of the highest significance to Cracow's identity. This has been reflected in the soft shape of the glazed facade of its foyer, opening towards the river and perfectly visible from the side of the transit artery and the opposite riverbank, on the side of Kazimierz. This glazed wall "entwines" the building, also covering its south-eastern corner, where an entrance to the building was designed in an apparently random location. The large, paved squares located to the south and west of the building are almost always occupied by parked cars. This prevents them from fulfilling the role they were created for, generating extensive non-places, undesirable in city centres. According to numerous critics, these spaces should have been placed from the side of the major circulation routes, something that would have complied with previous regulations for the area and created a proper public space for the building's foreground, linked with the riverside boulevards. This has been confirmed by urban designs of the rehabilitation of this part of the city, backed by many years' worth of studies and simulations (Bojanowski, 2013), whose results were not fully taken into consideration during work on the competition programme, and therefore also during the design stage. Because of its functional and spatial solutions, it is a highly introvert space of culture, one that does not form proper relations with the city's public space system - access to the Vistula River boulevards is currently provided by either a busy roundabout or by a distant, unsafe underground passage (DudzicGyurkovich, 2018). ICE requires the establishment of better relations with the context. Perhaps, despite the building's completion, it is not too late for this, as proven by European examples, particularly those of Barcelona (Dudzic-Gyurkovich, 2019; Gyurkovich, 2019).

Behind yet another river bend, following its course further downriver, is the Municipal Engineering Museum, tastefully arranged in the buildings of a historical tram depot. It was located near the former gasworks and power plant on the Kazimierz-side shore of the Vistula. In this place, the urban structure of the historic town of Kazimierz, which had once been surrounded by defensive walls, was located a little further away from the river, on whose shores there were piers and their associated storage buildings. Over a hundred years ago, this made it possible to build numerous buildings and infrastructural structures necessary to accommodate the expanding and modernizing city. The museum was established in the depot's meticulously restored halls, as well as in some of its smaller buildings, with exposed cast iron and timber structural elements. It is accessible from the side of Św. Wawrzyńca Street and, despite its proximity, it practically cannot be seen from the river.

ACE, 15 (4.5) CC BY-ND 3.0 ES | UPC Barcelona, Spain | Vistula River Valley in Cracow: from an Urban Barrier to a 12 New Axis of Culture in the Scale of the City. DOI: http://dx.doi.org/10.5821/ace.15.45.9913 
The museum is currently preparing to expand. Because of its historical context and restrictions associated with architectural conservation, a decision has been made to use its existing underground section and to extend it for this purpose, nearly doubling its exhibition space in the process. The relation between the boulevards and the museum, similarly to that of the entirety of Kazimierz with Podgórze, has been significantly improved by the Father Bernatek bicycle and pedestrian bridge, that was opened for use in September 2010. The structure was built as an effect of an architectural and urban design competition (designed by A. Getter and M. Dąbek with team), at the site of the former Podgórski bridge, becoming an important tourist attraction. Another, similar bridge, in Ludwinów, has been awaiting construction for over 10 years (Zuziak, 2018).

Figure 6. Cricoteka on the south bank on Vistula within the inner-city portion of river valley

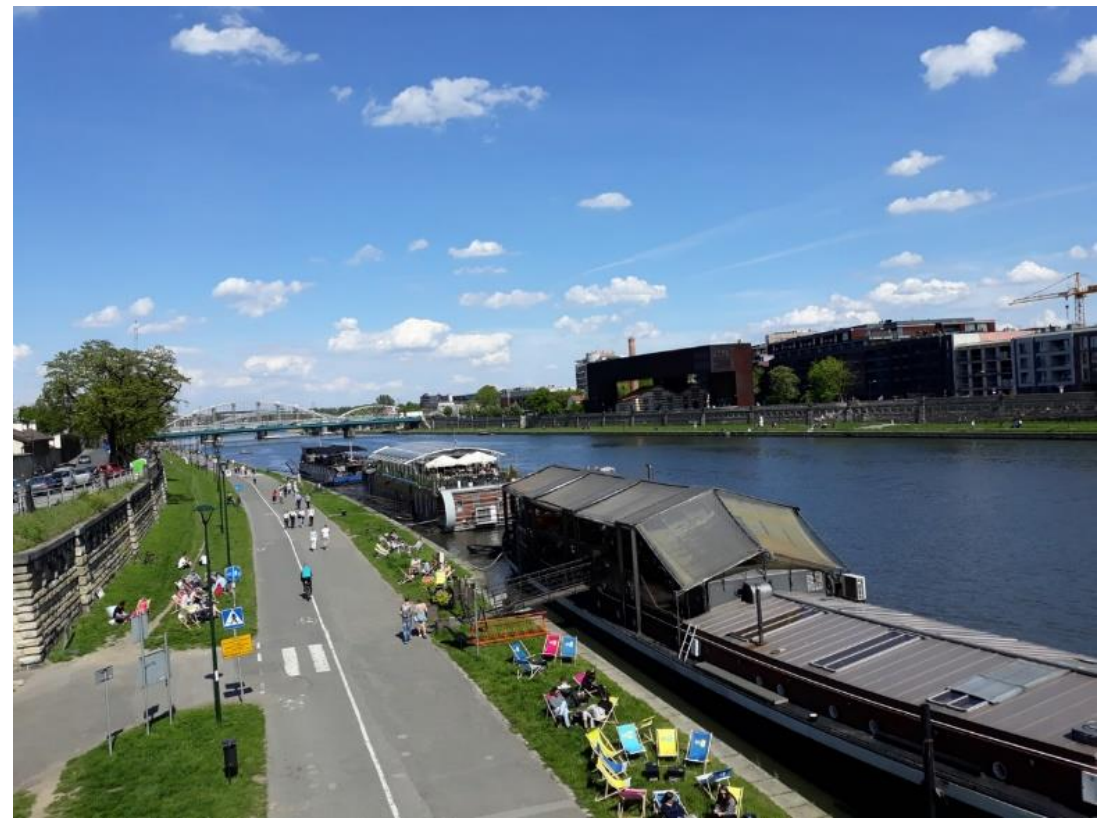

Source: photo by M.Gyurkovich, 2019

The Cricoteka, yet another cultural space project in Cracow, built on the "inferior", Podgórze-side bank of the Vistula, had to face a slightly different context (Fig.6) than the Manggha Museum or the ICE Congress Centre. Cracow's Podgórze district was a sparsely populated and unwanted part of the city up to the beginning of the twenty-first century, partly because of its difficult wartime history. At present, the district is undergoing a transformation process and is turning into a lively fragment of urban tissue (Gyurkovich et al., 2016). The Cricoteka-a new building, meant to house an institution founded by Tadeusz Kantor himself in 1980, which was housed in many places around the Old Town, was built because of an international competition that ended over a decade ago, in 2006. The winners were: IQ2 Konsorcjum, composed of the Krakow-based design companies: Wizja (directed by S. Deńko) and nsMoonStudio (Tomczak, 2014). The formal and legal conditions of conducting real estate development processes in Poland caused it to be completed only relatively recently, as the building was officially opened in September 2014. An exposed plot on the Podgórze side of the Vistula river boulevards, opposite Kazimierz, and its crowds of visiting tourists, was chosen for this prestigious and internationally recognised project, in part because of Tadeusz Kantor himself. It is located directly near the river, near a retaining wall erected there during the period of royal-imperial Austria, which was used to regulate the inner-city section of the Vistula, giving it the form, it has today. It was the site of the buildings of the small Podgórze Power Plant that was erected there in 1900. The urban regeneration of the neglected post-industrial heritage structure and its skilful blending with the modern cultural building became one of the major design assumptions.

ACE, 15 (4.5) CC BY-ND 3.0 ES | UPC Barcelona, Spain | Vistula River Valley in Cracow: from an Urban Barrier to a 13 New Axis of Culture in the Scale of the City. DOI: http://dx.doi.org/10.5821/ace.15.45.9913 
The new Cricoteka building features a comprehensive functional programme, including: the Tadeusz Kantor Museum (permanent exhibition), an exhibition centre (temporary exhibitions), a theatre and conference centre (in the former power plant buildings), a library with a reading hall, a modern centre for the research and documentation of the history of theatre and the visual arts, as well as a multilevel foyer, a bookstore, and a coffee shop, in addition to storage spaces and backrooms. "This alone places the building in the group of hybrid cultural buildings, in addition to its being a hybrid of a modern building and a historical power plant, in which the city's public space blends with the structure of its massing" (Tomczak. 2014, pp. 68-69). This creation of a space of culture, closely tied with accessible pedestrian path sequences at the upper level of the boulevards, was made possible thanks to the use of a bridge-like structural system. A part of the building forms a distinct, impossible bridge (Tomczak, 2014). This suspended structure resting on two legs (that house the necessary circulation and technical shafts) above the building of the old power plant is the most characteristic element of the design, truly monumental when compared to the existing structures nearby (Purchla and Sepiot, 2015; Gyurkovich, 2019). It is also the only contemporary structure visible above ground level. In this form, most of the programmatic elements were placed high above the boulevards, while the remaining ones were placed on the underground levels. The level of the city includes only the postindustrial buildings that have undergone adaptive reuse, along with an accompanying, small square that is partially covered by the new structure finished with mirrors from below, so the public space is "doubled"- one real, and another "reflected".

Figure 7. Inner-City Vistula River Valley (Vision 2030-50) new connectors over the river

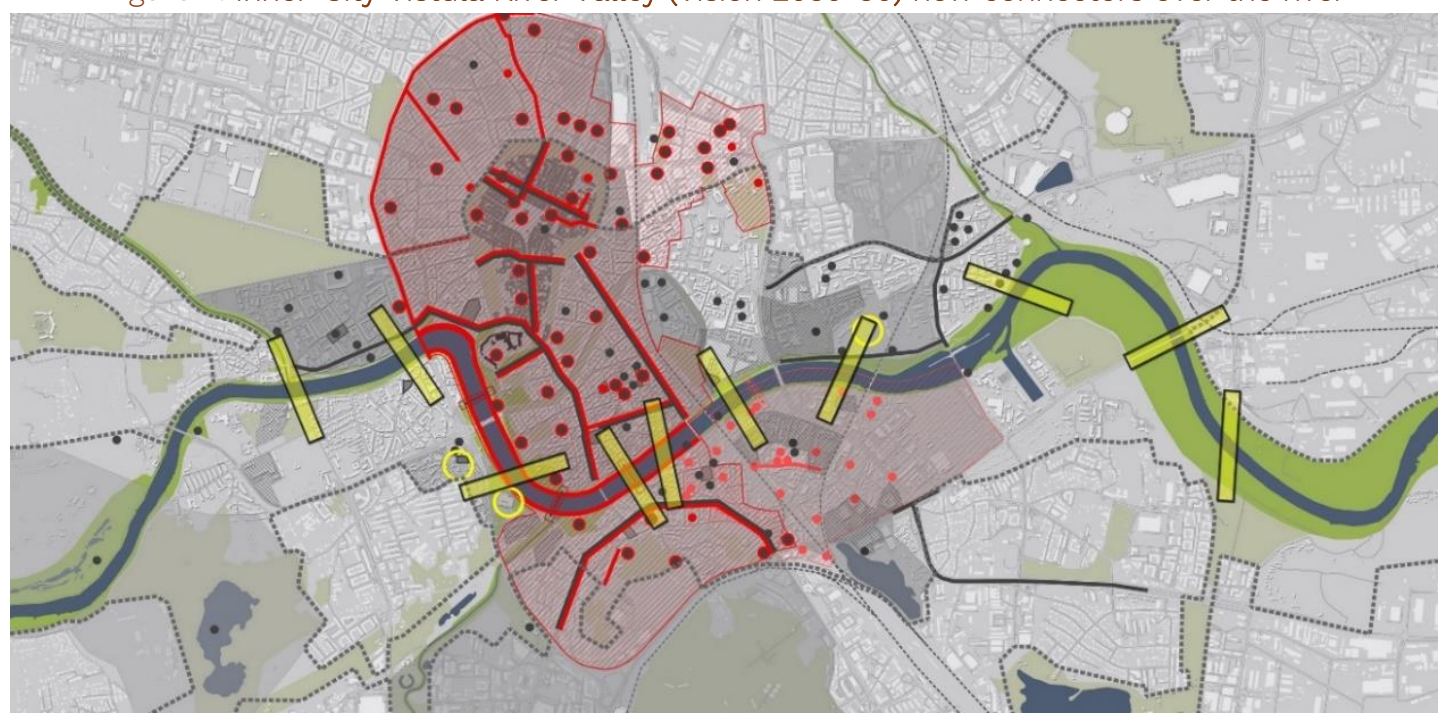

Source: Drawn by A. Sarga (Gyurkovich et al., 2017), courtesy of Cracow City Council.

The dynamic massing clads in a rusting material that corresponds with the identity of the place, together with the surviving brick smokestack and clinker-brick building of the old power plant (transformed into theatre), creates a new mark in the city-a strong form. It has been acknowledged both by the city's residents, the tourists visiting Cracow, as well as by the professional community. Interesting formal measures have made it possible to free up a significant portion of the small plot from development and obtain a generally accessible public space in the form of a square, one that is necessary to the functioning of a contemporary cultural institution. It has been linked with the city's structure of public spaces in a much better manner than similar spaces discussed in the first example. Its placement at the highest level of the boulevards along with its view of the panorama of the historic urban complex of Cracow and Kazimierz, placed on the UNESCO World Heritage Sites List in 1978, is an attraction in and of itself, independently of its programmatic offering. The construction of an additional footbridge, suggested in the Model (Gyurkovich et al., 2017), which would be a continuation

ACE, 15 (4.5) CC BY-ND 3.0 ES | UPC Barcelona, Spain | Vistula River Valley in Cracow: from an Urban Barrier to a 14 New Axis of Culture in the Scale of the City. DOI: http://dx.doi.org/10.5821/ace.15.45.9913 
of the course of Dajwór Street on the Kazimierz bank of the Vistula and would end at the square on the side of Podgórze (Fig. 7), together with other pedestrian connectors, could further enrich this already perfectly functioning space of culture..

\section{Conclusion}

The success of the abovementioned project in spatial terms, but perhaps most importantly, economic, and tourism-related ones, has caused Cracow's and Lesser Poland's leaders to decide to continue with the idea of erecting buildings and complexes associated with culture along the shores of the Vistula. Numerous planning and academic publications, including those prepared by the authors as a team, have not remained without influence on this turn of events. Three new projects are currently being planned. The first is the planned construction of a complex devoted to music in Grzegórzki, near Kazimierz (on the northern bank). It is to be composed of two parts-a new Musical Academy Campus with a concert hall, and the Music Centre. The proposal of the first, by F.O. Gehry and his team, was selected through a competition in March 2017. The design, similarly, to the concept of erecting a new cultural complex in the context of developer housing estates and the relics of Austrian forts itself, has, typically for Cracow, sparked a heated debate and great controversy (Wantuch-Matla, 2013). In autumn 2018, a competition was organised for the design of the Music Centre and the City Park, a new building for the philharmonic's orchestra on a plot adjacent to the complex being discussed. A Polish-Italian consortium: SBS Engineering Group with 3TI Progetti Italia, won this competition. The Music Centre is to be connected to the Music Academy's teaching complex, a city park, as well as recreational and service areas. The intention is to construct a hybrid complex, in which the space of culture and the park area are meant to become major elements. Due to the political conflict within the city, this investment would be, unfortunately, at least postponed. Another two-stage architectural and urban design competition was announced in the first part of September 2018, aimed at creating a mixed-use literature centre named "Centre for Literature and LanguagePlanet Lem", as a transformation of the historic Salt Storage on the southern, Podgórze-side bank, immediately adjacent to the river. In spring 2019 an interesting design with a delicate spatial expression by the Warsaw-based design company JEMS Architekci was selected. Upon construction, the complex would become a multi-threaded space of culture unique on the scale of the city, with a small-town scale that is so distinct of Podgórze, with a minimalist architecture aesthetic. Paradoxically, the design perfectly references the futuristic literary work of Stanistaw Lem (1921-2006), Poland's most outstanding science fiction writer.

It appears that creating a dense network of complexes and buildings of culture, linked with a green park along the shores of the Vistula, can significantly and positively alter the reception and functioning of this part of the city and the river valley within city limits. The project of establishing a network of pedestrian and bicycle links postulated by some members of the team from 2017 (Gyurkovich et al., 2017) could lead to better integration of currently built spaces of culture. As a result, it could aid in their success in the social and spatial dimension, as well as neutralise the urban barrier that the Vistula River continues to be (Racoń-Leja, 2019). But, perhaps most importantly, it can bring an end to perceiving the river as a mental barrier, one that separates privileged districts from those less so. However, urban design and planning interventions that could facilitate the carrying out of holistic tasks that aid in the urban regeneration of Cracow's riverside spaces on the scale of the entire city are still required.

ACE, 15 (4.5) CC BY-ND 3.0 ES | UPC Barcelona, Spain | Vistula River Valley in Cracow: from an Urban Barrier to a 15 New Axis of Culture in the Scale of the City. DOI: http://dx.doi.org/10.5821/ace.15.45.9913 


\section{Autorship}

The scope of work was divided: Mateusz Gyurkovich focused on urban composition of Cracow, structural-functional relations of the old and newly introduced cultural elements and formulating the idea of an axis of culture; Karolina Dudzic-Gyurkovich focused on urban morphology and defining the urban barriers; Agnieszka Matusik focused on the hydrological system of river valley within the city; Kinga Racoń-Leja focused on the development of urban structure over the centuries.

Conflict of interests: The authors declare that there is no conflict of interests.

\section{Bibliography}

Audirac, I., Fol, S., Martinez-Fernandez, C. (2010). Shrinking Cities in a Time of Crisis. Berkeley Planning Journal, 23 (1), 51-57. DOI: https://doi.org/10.5070/BP323111430

Benach, N. (2004), Transforming Barcelona: The Renewal of an European Metropolis, London-New York, UK-USA: Routledge

Benedet, V., Azpeitia, A., Azkarte, A.(2020) Landscape and Urbanism in the 21st Century. Some Reflections on the State of Affairs. ACE: Architecture, City and Environment, 15 (43), 8987, 1-14. DOI: http://dx.doi.org/10.5821/ace.15.43.8987

Bojanowski, K. (2013), Strategia dla Krakowa- koncepcja rozwoju przestrzeni publicznych. Monolog o polskiej urbanistyce, Kraków, Poland: Wydawnictwo Politechniki Krakowskiej.

Burda I. M., Nyka L. (2017) Providing Public Space Continuities in Post-Industrial Areas through Remodeling Land/Water Connections, IOP Conference Series: Materials Science and Engineering. 245, 082037, DOI: https://doi.org/10.1088/1757-899X/245/8/082037

Chávez Alaffita, L., Hernández Bonilla, M., Benítez Badillo, G. (2020) Intervención y transformación de áreas naturales, en el contexto nanocuenca, como espacios públicos en la ciudad de Xalapa-México. ACE: Architecture, City and Environment, 15(44), 8984. 1-23, DOI: http://dx.doi.org/10.5821/ace.15.44.8984

Conzen, M R G. (1960). Alnwick, Northumberland: A Study in Town-plan Analysis. London, UK: Inst. of British Geographers.

Conzen, M. R. G. (2004).Thinking about Urban Form: Papers on Urban Morphology, 1932-1998. Oxford, UK: Peter Lang.

Dudzic-Gyurkovich, K., Gyurkovich, M. (2008), The Vistula river boulevards - the green "salon" of Cracow, Technical Transactions, Series Architecture, 105 (2-A), 151-158.

Dudzic-Gyurkovich, K. (2016), City recreation zones as an element in a strategy of overcoming urban barriers, Housing Environment, 16, 34-41.

Retrieved from: https://www.ejournals.eu/housingenvironment/16(2016)/art/8085/

Dudzic-Gyurkovich, K. (2018) Public space and urban barriers in Cracow. Analysis of existing state, Technical Transactions, 115(1), 19-34. DOI: https://doi.org/10.4467/2353737XCT.18.002.7953

Dudzic-Gyurkovich, K. (2019). Pokonywanie barier urbanistycznych zwiqzanych z układami transportu na obszarze Metropolii Barcelońskiej - wybrane problemy, Kraków, Poland: Wydawnictwo Politechniki Krakowskiej.

ACE, 15 (4.5) CC BY-ND 3.0 ES | UPC Barcelona, Spain | Vistula River Valley in Cracow: from an Urban Barrier to a 16 New Axis of Culture in the Scale of the City. DOI: http://dx.doi.org/10.5821/ace.15.45.9913 
Durán Vian, F., Pons Izquierdo, J.J., Serrano Martinez, M.(2020) ¿Qué es un río urbano? Propuesta metodológica para su delimitación en España. ACE: Architecture, City and Environment, 15(44), 9035, 1-30. DOI: http://dx.doi.org/10.5821/ace.15.44.9035

Encyklopedia Krakowa (2000), Warszawa-Kraków, Poland: PWN.

Gyurkovich, J., Matusik, A., Suchoń, F. (eds.), (2016) Cracow: selected problems of the urban structure evolution, Kraków, Poland: Wydawnictwo Politechniki Krakowskiej.

Gyurkovich, M. (2012), In search of the urban composition of sub-centres in polycentric European metropolises, ACE - Arquitectura, Ciudad y Entorno, 6 (18), 251-264. DOI: https://doi.org/ 10.5821/ace.v6i18.2552

Gyurkovich, M. (2013), Hybrydowe przestrzenie kultury we współczesnym mieście europejskim, Kraków, Poland: Wydawnictwo Politechniki Krakowskiej.

Gyurkovich, M., Szarata A., Zuziak, Z.K., (2017), Model Przestrzennej Struktury Krakowa. Perspektwa planistyczna. Etap II - Zdefiniowanie modelu przestrzennej struktury Krakowa (unpublished reaserch project for Office of Spatial Planning of City Council of Cracow) Institute of Urban Design, Faculty of Architecture, Cracow University of Technology, Kraków

Gyurkovich, M. (2019). Polskie przestrzenie kultury, Kraków, Poland: Wydawnictwo Politechniki Krakowskiej.

Haase, A., Rink, D., Grossmann, K., Bernt, M and Mykhnenko, V.(2014), Conceptualizing urban shrinkage. Environment and Planning A, Vol. 46, no. 7, 1519-1534.

Harvey, D. (2012). Bunt miast. Prawo do miasta i miejska rewolucja. Warszawa, Poland: Fundacja Nowej Kultury Bęc Zmiana.

Izdebski A., Szmytka R. (Eds.) (2018), Ekobiografia Krakowa, Kraków, Poland: ZNAK Horyzont.

Jagodzińska, K. (2008), Dzielnice kultury-miasta w mieście. Przypadek Europy Środkowej, Kultura i Polityka, no. 4,.46-62.

Kadtuczka, A. (2010), The Main Market Square in Cracow: The Underground Museum- its architecture and conservation. En: J. Jasieńko et al. Florence \& Cracow- Two Cities in Europe- Common Cultural Heritage, (pp.429-450) Kraków, Poland: Universitas.

Kadłuczka, A. (2015), Conservatio est continua creatio- or the doctrine of heritage protection as a component of existential space, Journal of Heritage Conservation, no. 43, 69-77.

Kantarek, A. (2008), O orientacji w przestrzeni miasta, Kraków, Poland: Wydawnictwo Politechniki Krakowskiej.

Kantarek, A. (2014), Time and space of the city, Technical Transactions Series A, 111 (1-A,), 105-125.

Konior, A., Pokojska, W. (2020) Management of Postindustrial Heritage in Urban Revitalization Processes, Sustainability, 12 (12), 5034, 1-19. DOI: https://doi.org/10.3390/su12125034

Kropf, K. (2017), The handbook of urban morphology. Chichester, UK: John Wiley \& Sons.

Lynch, K. (1984), Good City Form, Massachusetts, USA: The MIT Press.

Lynch, K. (1960), The Image of the City, Massachusetts, USA, London, UK: The MIT Press; polish edition (2011) with the introduction by W. Kosiński: Obraz miasta, Kraków, Poland: Archivolta.

ACE, 15 (4.5) CC BY-ND 3.0 ES | UPC Barcelona, Spain | Vistula River Valley in Cracow: from an Urban Barrier to a 17 New Axis of Culture in the Scale of the City. DOI: http://dx.doi.org/10.5821/ace.15.45.9913 
Matusik, A. (2018a). River valley as a hydrological/urban dynamic system in the structure of contemporary city. Technical Transactions, 115(2), 57-68. DOI: https://doi.org/10.4467/2353737XCT.18.020.7993

Matusik, A. (2018b). River. Transformation or Metamorphosis. Housing Environment, n. 22, 130-139. DOI: https://doi.org/10.4467/25438700ŚM.18.005.8515

Matusik, A., Racoń-Leja, K., Gyurkovich, M., Dudzic-Gyurkovich, K. (2020) Hydrourban spatial development model for a resilient inner-city. The example of Gdańsk. ACE: Architecture, City and Environment, 15, (43), 1-21. DOI: http://dx.doi.org/10.5821/ace.15.43.9211

Międzynarodowe Biennale Architektury. (2019). The programme of the event. Retrieved from: http://mba2019.sarp.krakow.pl/program/?lang=en

Mironowicz, I. (2007), Drogi rewitalizacji zdegradowanych struktur miejskich, Architectus, 1-2 (21-22), 93-108.

Mumford, L. (1961). The City in History. Its Origins, Its Transformations, and Its Prospects. New York, USA: A Harvest Book.

Nowacka-Rejzner, U. (2019), River and Riverside Areas - in the Contexts of Shaping the Urban SpaceCase Study, IOP Conference Series: Materials Science and Engineering. 471, 112088, 1-11. DOI: https://dx.doi.org/10.1088/1757-899x/471/11/112088

Nyka, L. (2013). Architektura i woda-przekraczanie granic. Gdańsk, Poland: Wydawnictwo Politechniki Gdańskiej.

Oswalt, P. (2006). Introduction. Shrinking Cities, Volume 1 International Research. Vol. 1, 1-17.

Parcerisa Bundó, J. (2014) Barcelona, Urbanisme Segle XX, Vigila el mar, vigila el muntanyes, Barcelona, España: MONTABER

Pazder, D. (2018). Obszary kreatywności - creative syntax - jako czynnik ożywiania śródmieść. Wybrane zagadnienia, Poznań, Poland: Wydawnictwo Politechniki Poznańskiej.

Porębska, A., Godyń, I., Radzicki, K., Nachlik, E., Rizzi, P. (2019) Built heritage, sustainable development, and natural hazards: flood protection and UNESCO world heritage site protection strategies in Krakow, Poland, Sustainability, 11 (18), 1-26. DOI: https://doi.org/10.3390/su11184886

Purchla J. (1990). Jak powstat nowoczesny Kraków, Kraków, Poland: Wydawnictwo Literackie.

Purchla, J. and Sepioł, J. (Eds.) (2015). Form Follows Freedom, Architecture for Culture in Poland 2000+, Kraków, Poland: ICC.

Racoń-Leja, K. (2011), Kanat krakowski-niewykorzystany potencjat, En: Januchta-Szostak A. (ed.) Społeczne i krajobrazowe walory wody w środowisku miejskim (pp.71-78), Poznań, Poland: Wydawnictwo Politechniki Poznańskiej.

Racoń-Leja, K. (2019) Managing the water in the context of Krakow development history.

En: K. Ostrowska-Wawryniuk (ed.), ICAADE 2019: 3rd International Conference on Amphibious Architecture, Design and Engineering: Shifting the Boundaries, Faculty of Architecture Warsaw University of Technology, 13-16.10.2019: book of abstracts (p.53); Warsaw, Poland: FA WUT

Sassen, S. (1991). The global city. 2nd ed. Princeton; Oxford, USA-UK: Princeton University Press.

ACE, 15 (4.5) CC BY-ND 3.0 ES | UPC Barcelona, Spain | Vistula River Valley in Cracow: from an Urban Barrier to a 18 New Axis of Culture in the Scale of the City. DOI: http://dx.doi.org/10.5821/ace.15.45.9913 
Seruga, W. (2018). Greenery and water in contemporary urban complexes. Housing Environment, $N^{\circ}$ 22, 174-249, DOI: http://dx.doi.org/10.4467/25438700ŚM.18.029.8710

Słącz, G. and Ingarden, K. (Eds.) (2014). ICE Kraków Congress Centre, Kraków, Poland: KBF.

Stownik Języka Polskiego, online version, Retrieved from: https://sjp.pwn.pl/szukaj/bariera.html, accessed on February 2017

Tomczak, M. (October, 2014). Niemożliwy most, Architektura \& Biznes, 64-73.

Wantuch-Matla, D. (July-August 2013). Weiji po krakowsku- debata nad przyszłością Centrum Muzyki W Krakowie, Architektura \& Biznes, 18-21.

Wejchert, K. (2008). Elementy kompozycji urbanistycznej. 2 edition, Warszawa, Poland: Arkady.

Węcławowicz-Bilska, E. (2019), Recipe for a city, IOP Conf. Ser.: Mater. Sci. Eng. 471, 112048, 1-10. DOI: https://doi.org/10.1088/1757-899X/471/11/112048

Whitehand, J. (2006). The Fringe-belt Phenomenon and Socioeconomic Change. Urban Studies. 2006. Vol. 43, no. 11, 2047-2066.

Whitehand, J. (2007). Conzenian urban morphology and urban landscapes. 6 th International Space Syntax Symposium p. ii-1-ii-9.

Ziobro, A. (2018). Planning-related factors of the quality of residential environment in modelling of the functional spatial structure of Cracow, Technical Transactions, 115 (2), 97-108. DOI: https://doi.org/10.4467/2353737XCT.18.023.7996

Zuziak Z.K. (2018) Centrum i architektura miasta- przesłanie z Krakowa, En: Z. K. Zuziak et al. (eds.) Centra miast metropolitalnych w Polsce. Urbanistyka a polityka przestrzenna., (pp.235-259), Katowice, Poland: Wyższa Szkoła Techniczna w Katowicach.

ACE, 15 (4.5) CC BY-ND 3.0 ES | UPC Barcelona, Spain | Vistula River Valley in Cracow: from an Urban Barrier to a 19 New Axis of Culture in the Scale of the City. DOI: http://dx.doi.org/10.5821/ace.15.45.9913 